\title{
Embracing Technology Advancement in Banks for the Marketing Orientation Efforts in Malawi
}

\author{
Article by Enwell Pickford Tomoka Kadango \\ Texila American Unversity, Guyana, South America \\ E-mail: enwellkadango@gmail.com
}

\begin{abstract}
“What helps people helps business." Leo Burnett.

This paper investigates the implementation of the marketing concept thereby allowing entrenchment of marketing orientation in the service industry in Malawi. Of the service industry, banking was the focus in this study to see how marketing orientation and technology have enabled the implementation of the marketing concept. If businesses including banks are to be marketing oriented, they must implement fully the marketing concept. In doing so, they must have the marketers at the top table. This article aims to review the use and embracement of technology in banks to enhance its marketing orientation. The investigation was done through qualitative methodology where top-marketing executives in the banks participated in the study in depth interviews. Top marketing executives were interviewed using a discussion questionnaire to understand the organizations structure, technology in use and the level of involvement in decision-making. Data analysis made use of thematic grouping to gain the direction, behavior and practice in the banking industry to determine the level of marketing professionals' engagement in decision-making and technological use in the same efforts that relate to marketing orientation and implementation of the marketing concept.

Generally, the banking industry does not have a fully-fledged and well-resourced marketing department that would effectively implement the marketing concept thereby being fully marketing oriented. Lack of resources both financial and human capital for marketing department is apparent in the banking sector.
\end{abstract}

Keywords: marketing orientation, marketing concept, banking technology, banking services

\section{Introduction}

Service industry in Malawi, just like in many other countries contribute significantly to the economic growth of the country. Both manufacturing and service sector of Malawi play a significant role in the economic development of Malawi. United Nations (2015) reports that service sector in Africa countries contributes about $50 \%$ of the countries' economic growth. However, Malawi though primarily agriculturebased economy (Bingu wa Muthalika 2006), much more contribution to the Gross Domestic Product (GPD) which stands at $67 \%$ emanate from the manufacturing and service sector (https://www.cia.gov). Some studies have been done in the manufacturing sector to review its contribution and placement in the economy of Malawi but very little has been done on service sector especially the banking industry. Service sector contributes even more than the manufacturing sector with well over 70 percent influence on the combined GDP contribution of both manufacturing and services (International Trade Centre 2012). Banking sector being one major sector of the service part of the economy makes major strides in the economy. Technological advancement and its impact on marketing orientation visa vis implementation of the marketing concept is an area that has not been researched in as far as Malawi is concerned. It is clear that, the implementation of marketing concept depends on the orientation of the company, which in modern times has some enhancement of technology. However, has technology in its advancement played its role in enhancing the marketing orientation or not in this sector? This among others will be the key area of this study. Kholi and Joworski (1990) explain both marketing concept and marketing orientation in that marketing concept constitute a way of thinking about an organization, its products and customers. It is a set 
of attitudes towards the market whereas marketing orientation looks at providing steps needed to develop this philosophy in the company as a behavioral trait. Marketing orientation also looks at the future not only current customers, competitors and interfunctional coordination. Marketing orientation is therefore a type of business culture, a behavior, an organization culture that helps separate superior value to customers and keep them loyal as an asset for future revenue stream.

The banking sector in Malawi has evolved since independence in 1964. From a handful of banks of about three in number before the year 2000 to now over ten banks in the country. The marketing orientation being a behavioural demonstration of an organization comes from the leading role of the top marketing executives. It is clear in Malawi that the banking sector has over time not been keen to have a fully resourced marketing function. Recently, there has been an increase in recruitment of marketing professionals in banks as competition stiffens. For a large part of the $20^{\text {th }}$ centuries, it was mainly the manufacturing sector that has had well defined marketing departments driving marketing orientation and implementation of the marketing concept across the organizations. Today, with increasing competition, many banks have a marketing department though in varying sizes and resourcing. Still, many gaps exists in the resourcing of this important function in an ever-increasing competitive industry. This study aims to uncover the gaps that exist in the banking sector in as far as marketing resourcing is concerned and whether the banking industry has taken advantage to align its marketing orientation with the advancing technologies, the world is ever experiencing. Some parallels will be drawn to compare the resourcing nature of a bank against any other service company in this case mobile company, which has shown significant presence of marketing orientation. Mobile companies have embraced the technological advancement in a much visible way such that some of the banking service requirements are now in the hands of mobile companies ably complementing the need for financial inclusiveness of the unbanked. While the banking services require customers to have a certain set of mandatory minimum cash mostly from employed or business people, penetration for the banks has remained low for Malawi currently at 15\%. Dupas, Karlan, Robinson, Ubfal (2017) states that $85 \%$ of the population in Malawi do not own a bank account. Mobile service penetration at 38\% in 2013 (Macra 2015) is far higher despite being around for just under 20 years as opposed to the banks, which have been around for close to 50 years. It is believed that the level of marketing orientation in banks have contributed to this low uptake of financial services and low penetration of the banking sector compared to mobile sector. It is also envisaged that a strong part of the major impact to this problem has been the way banks have resourced its marketing department as well the levels are they have placed marketing professionals in the organization. The top table in most banks lack the presence of marketing professionals and it may appear that these important professional play a second fiddle in this industry. Some banks will have heads of Marketing at the top table of executives where strategies are discussed while some banks have single resources somewhere in the lower ranks with no assistance. The questions that lingers around is who then would drive the implementation of the marketing concept which according to Kholi, Bernard and Joworski (1990) is the cornerstone of the marketing discipline and also who would ensure that the bank is marketing oriented for it to better service its customers.

Concisely, this study will focus on reviewing the following:

1. How banks resource their marketing department

2. Whether marketing executives participate in top level decision making

3. Whether technology is used to drive services delivery to its customers especially with advancing technology the world has witnessed

4. Are there signs of marketing orientation in the banking sector and implementation of the marketing concept critical in its quest for growth amid competitive environment

It is believed that the study will valuably enhance the orientation of the service sector of the economy to help it grow further as the sector play a major role in the GPD of the country. 


\section{Objectives of the study}

The study's broad objective is to assess the level of marketing orientation of the banks in Malawi and to what extent do they implement the marketing concept, which is critical in their quest for growth. It also look at the level of usage of technology in its customer services to ensure timely and smooth interactions with its customers especially as the world has witnessed a boom in technological advancement. Notwithstanding this, all this to happen, there is need for the process to be governed by marketing personnel at the highest level of the bank's organization.

\section{Specific objectives}

1. The nature of resourcing of marketing professionals in the banking industry

2. The level of placement of marketing professionals in the banks organization's structure

3. The level of usage of technology in its service drive to its customers especially with advancing technology the world has witnessed

4. The level of marketing orientation in the banking sector and the implementation of the marketing concept critical in its quest for growth amid competitive environment.

\section{Defining the research problem}

In the much taunted service sector bolstering with profits year on year, how much is the profit contribution coming from marketing impact. In the 2016 financial announcements for the banks in Malawi, it shows that they are doing extremely well with super profits. Standard Bank, an international bank announced its profits at K19b an equivalent of USD26m (The Times March 2, 2017). In parallel, National Bank the archrival in its financial report for 2016 (Nation newspaper April 12, 2017) reported a staggering K16b (USD 21m) even amid acquisition of Inde Bank in the course of the year, which has had to affect the bottom line of the bank. However, when you look into their marketing structures, resourcing and position in the organogram, one wonders if indeed the banks are thriving on the well-implemented marketing concept or these profits are merely a chance coming from the sort of economy that is punitive in its service costs. How much of the technology is in use in a bid to offer excellent service to its customers especially if the marketing functions are dismally resourced.

It is against this background that this research aims to uncover the contribution marketing has and or the impact of technology on the bank, through the assessment of the banking services, the use of technology and the impact of the marketing professionals visa vis the marketing concept implementation as a measure of their marketing orientation. With the resource levels in the marketing department, how are they coping with this mammoth task of implementing the marketing concept? Are they well represented at the top table is a key question to answer.

\section{Conceptual framework}

This study is informed by the concept of marketing, which is critical in the quest for marketing orientation. For all the work done in the marketing department, it is grounded in this marketing concept, which defines all the axillary areas that make up the marketing. Implementation of such a concept is critical to the achievement of the marketing orientation. With the advent of technology in the modern world, some of the processes necessary for the implementation of the marketing concept have been made easy. It is therefore important for the banks to apply fully the marketing concept. However, this may not be the case hence the study being undertaken. 
DOI: $10.21522 /$ TIJMG.2015.03.02.Art002

ISSN: $2520-310 \mathrm{X}$

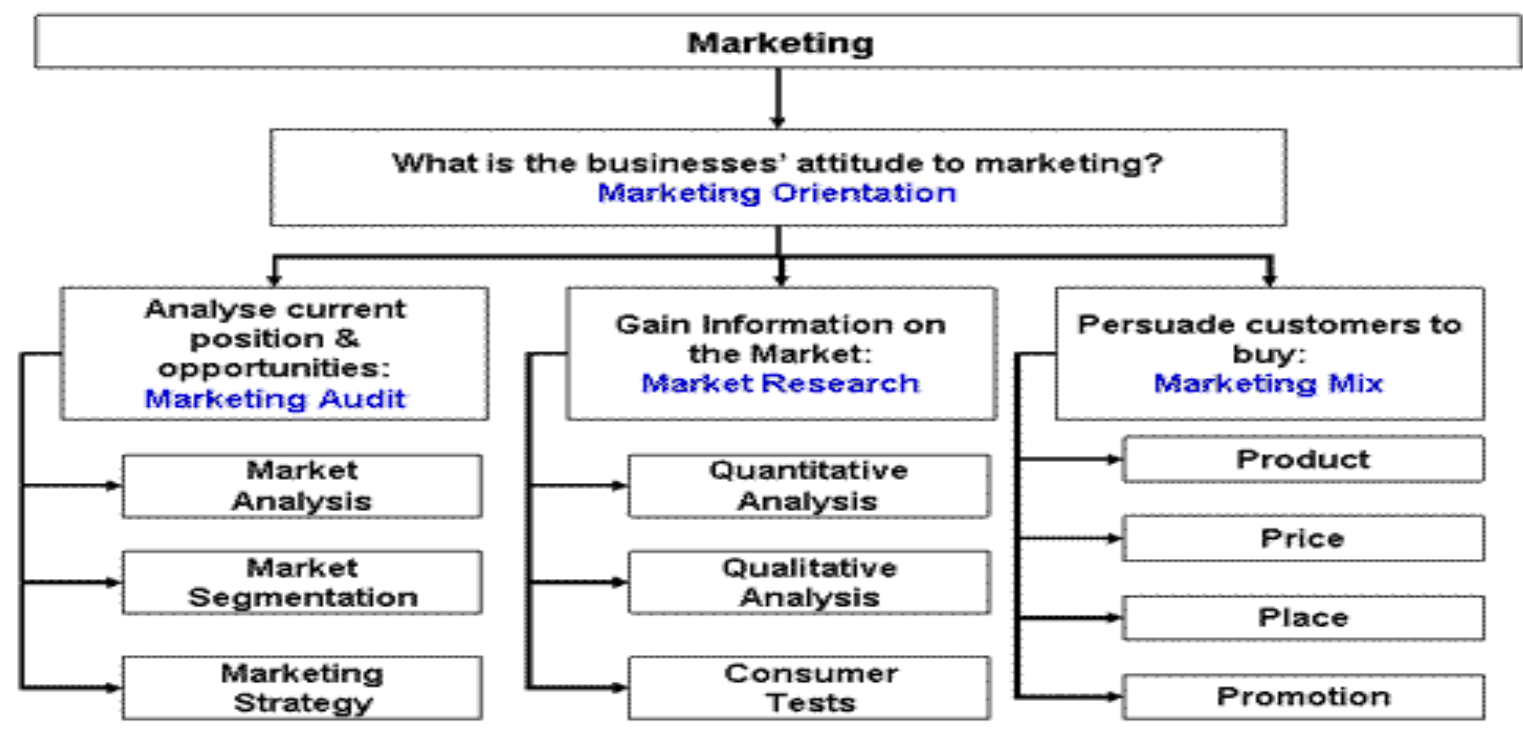

Figure 1.5. Conceptual framework - Marketing Orientation (source: Phillip Kotler)

Using this concept, marketing orientation, which is the overall focus of this study, refers to the development of attitude and practices that aim to maximize the company's adaptation to the market (Avlonitis and Gounaris 1997). This is broken down into marketing audits to know what is happening in the market, research work being carried out and the marketing mix. In this study, the aim is to check what the attitude of the banks is towards marketing and if the processes above are fully implemented and are supported with resource requirement. The study will also inform whether technology is in use to assist in the implementation of the marketing concept thereby being a marketing oriented organization.

\section{Introduction}

In this section of the study, a review of past studies will be carried out to form the basis to this study. The banking industry is particularly singled out as the focus of the study. First, literature looks at service industry in Malawi and its contribution to the economy

\section{Service industry in malawi}

Service industry is a critical sector in Malawi just as it is across the globe. This sector brings notable economic contribution even beyond the manufacturing sector in a general industry set up. In Malawi for example, service sector alone contributes $56 \%$ in value-added terms. Combined contribution of the manufacturing and service sector is well over $60 \%$. Of the total industry and service contribution to Malawi's gross domestic product (GDP) which stands at $67 \%$, service sector alone in Malawi takes a sizeable chunk of well over $70 \%$ contribution to value-added GDP (http://www.intracen.org). This makes service sector very critical to the value added side of the GDP. United Nations (2015) affirms this assertion in reporting that in Africa service industry contributes over 50\% of the GDP. Bingu wa Muthalika (2006) assents that Malawi's leading economic activity driver is agriculture that employs $80 \%$ of the workforce and responsible for over $80 \%$ of foreign exchange earnings for the country. Beyond being the mainstream of the economic activities, Agriculture drives national and household food security in Malawi. Today, service sector includes transport, consultancy, insurances, banks, healthcare, agencies and many more (Stigler 1956). In fact, whether it is a manufacturing or in deed an objective service industry, all businesses in the world are engaged in providing service in one way or another such that service activities are used 
throughout the manufacturing process and manufacturing value chain. In fact, even in service industry, some of the sectors not believed to be of service nature are classified as such. Main distinguishing factor is the fact that no physical product is involved then it is a service (www.nber.org). Products when manufactured and sold, somewhere a service is involved that is why there is customer service department. In discharging different duties, service is mostly used to gauge if that organization minds about its customers or not.

Banking sector is one of the most rapidly growing section of the service industry in Malawi. Currently, there are 10 banks in Malawi both local and international banks (http://www.iobmalawi.com). Service provided by these banks vary from one bank to another especially when it comes to customer service. Much as it is a fact that banks provide financial solutions to businesses, they compete on best service that includes convenience, attention to customers, responsiveness to customer needs, understanding its customers, footprint of the outlets for ease of access by its customers, lending rates and interest rates, prices charged for various services, innovation and branding among others (Deloitte 2014). For a bank to excel and do better, it must win the trust of its customers because these are money matters. Ernest and Young (2014) says a bank must win the trust of its customers in order to grow

\section{Competition in the banking sector and marketing resource}

Competition being riffle in these days, Brand Loyalty (2005) emphasizes that in a competitive world; brands must thrive and survive the stiff competition. Banking industry is not spared from this competition, the only way to gain more customers or to increase customer base is by offering the best service. Marketing people are tasked with managing the brand in any business. For the business to succeed, it needs a wellplanned marketing concept implementation. Brand loyalty (2005) informs that branding is now the most important aspect of the business and that whether the business is a bank or a toy seller, it is the brand itself that will dictate whether the business succeeds or fails. Customers are always on the move with unprecedented access to competing banks and to new type of financial service providers (http://www.ey.com). While it is clear that, most customers have several bank accounts, maintaining primary account in your bank is critical for business growth and improving market share because primary bank customers use that account much more often than other accounts. Malawi in the early years of independence did not have marketing department in the banks and therefore marketing personnel in the banks were nonexistence. Over time, banks in Malawi have realizing the need for marketing department. As customer demands continued to grow amid competition in the country in the banking sector, there has emerged a need to employ marketers in the Banks. More and more marketing personnel have been recruited over time. However, the level of marketing department in some banks lacks the flair that is needed for an effective execution of the marketing concept. Most banks in Malawi are seen with one resource person or just a few people to act as a link between the media and the bank. When one compares the banking sector's marketing department, resourcing with other service sectors like mobile service provides or manufacturing companies, one would quickly notice the lack of personnel in the banking sector. The number of banks in Malawi has growth from very few in the 90s to at least over 10 banks in 2016. To make it worse, bank service penetration is amongst the lowest in Africa at 15\% of Malawi's population that is banked (Dupas et. al 2017)). Of late with the advancement of technology, mobile money services that are being provided, have many more customers who have otherwise been without bank accounts to accessing financial services. Mujeri (2016) reports that in recent years, mobile banking has emerged as the potent instrument for increasing outreach of financial services. Africa has produced one of the world's largest mobile banking service in the world from the East African countries of Kenya, Tanzania and Uganda. (Metre 2011) The entrenchment of mobile money service especially Mpesa has been phenomenal in getting the unbanked to start enjoying the services traditionally provided by the banks all along. Beyond provision of banking services, mobile money wallets have also come with easing transfers of money across the country and sometime regionally as well. Mobile banking service has also thrived on the backdrop of innovation and marketing which somehow testifies that marketing is critical in the banking service. In mobile companies, 
DOI: $10.21522 /$ TIJMG.2015.03.02.Art002

ISSN: $2520-310 \mathrm{X}$

the marketing department is well defined and well-resourced than is the case with banking service sector. It is some of the parallels that will be evaluated in this research to try to uncover the lagging behind nature of banks in recruiting and resourcing their marketing departments. The mobile paradox as per their main thrust, which is growing customer base to support the network then exciting these customers to use the network that has seen them register double digit growth for a number of years. Malawi for example, mobile service came around 1985 while the banks have been around for much longer. The customer base however, surpassed the bank customer base within two years of its introduction. This partly confirm that marketing plays a major role and must be well resourced to appreciate its impact. The aim of this research work it to review the presence of marketing professionals in the banking sector of Malawi. Traditional ways of marketing as practiced in other industries like the proxy of mobile business would be a good one to emulate as both businesses are dealing with customers base as core driver of business sustenance and growth.

\section{Introduction to research methodology}

The study will be exploratory in nature and qualitative through simple discussion guide that will engage the top marketing executive and or top executives in the banks. Desk research of the publications of the bank, reports and other sources of information shall be included in the data gathering which the author will undertake. The methodology of in-depth interview is appropriate in this study. Boyce (2006) defines indepth interview as an intensive interview that is conducted with selected few individuals (in this case employees of the banks purposely selected) to check their perspective of the use of technology in customer management as well as marketing orientation of their institutions. Detailed information about the thoughts of those interviewed is sought is this type of qualitative interview. Marketing orientation being behavioral issues, the in-depth interview presents a valuable methodology to capture the views from such service industry

\section{Research design}

A questionnaire discussion guide was used to collect data from selected top marketing official in the selected banks. An in-depth interview was conducted using a discussion guide / questionnaire. The discussion guide made use of the MAKTOR SCALE assessment, which aimed at reviewing the behavior of the bank in its efforts to provide better services, get feedback from its customers, know the competitive landscape and legal and regulatory framework prevailing (Kohli, Joworski, Kumar 1993). At first respondents were asked to participate in the study with google-generated questionnaire (https://docs.google.com) that was later followed up with telephonic discussions where the author needed to get further clarification and or dive deeper into some behavior issues. The analysis followed thematic approach as to what their behavior is in an effort to implement the marketing concept and gauge the level of marketing orientation. The results will show the level of technological involvement in the process of executing marketing activities.

\section{Sampling technique}

A purposeful sampling of the banks to participate in the study was done. At least two international banks and two local banks were selected purposefully. The respondents to participate in the discussion guide largely come from Marketing department and or other senior officers of the bank. Instead of focus, group, an in-depth interview was used to allow for identification of the employees and them being senior managers in different banks; it was not possible to put them into one group of focus group. All that was needed was to get the views on the topical research study about technology usage and marketing orientation. Also bearing in mind that the four selected banks could be at different levels of technology usage and marketing orientation behvour, it was proper to conduct an in-depth interview so that each one is able to describe their banks in more detail without considering others banks managers' presence. This type of methodology avoids biasness in data collection because the managers are not in one group and would not be trying to outdo one another but rather give what is right about their institution. Boyce (2006) states that in-depth 
interviews should be used in place of focus group in situations where those being interviewed may not be comfortable to discuss freely especially when it is critical to distinguish individuals clearly.

\section{Data collection}

Data was collected through a discussion questionnaire that was developed using google forms and administered electronically on line. The discussion questionnaire link was emailed to the respondent in the bank. Designated respondents filled the questionnaire on line and the responses are automatically saved in the same google form space. Provision was made to follow up the respondents if they did not comply in filling the questionnaire. This was to be done through telephone call and in one case; a face-to-face interview was made as a follow up. The total number of banks participating in this study is four. This being qualitative in nature, the marketing department was asked to choose whether they wanted to have its team members respond as a group in order to provide answers as to the processes in place. Technology was made use of in generating the discussion questionnaires on google application and respondents could easily type their responses into the system. This questionnaire guide link was emailed to respondents in the four banks through google forms (https://docs.google.com). Follow-ups was made with each bank to ensure full compliance. The author then took time to talk to some of the respondents telephonically and to gain more insights on some questions following their responses recorded. This further complemented the questionnaire such that it was easy to deep dive in some questions to pick up the behavior patterns in the banking industry.

\section{Data analysis}

Thematic analysis will be used to generate direction that banks have taken in the provision of services to its customers. Following from these thematic grouping, it will be easy to distil the behaviour that prevails on the bank and the utilization of technology to best serve the customers and to what level the marketing department is resourced including its top executive.

\section{Introduction}

In this chapter, the findings of the study in relation to the study objectives and questions as set out in the introduction in chapter one are presented discussed and interpreted offered. From the sample used, four banks were interviewed using the marketing top executive in the bank who responded to the discussion guide that was administered via in-depth interviews. All the four interviews that were planned one per each bank were achieved. From each of the banks, their top marketing executive participated in the research. This gives credibility to the findings as the very top marketing officers who are running the show participated. Efforts has been made to relate the findings with literature as a way of generating points of agreements and or disagreements in as far as technological usage and marketing orientation of the banks are concerned. To kick-start the chapter, a brief review of the sample characteristic and experience is presented

\section{Sample characteristic and respondents levels}

The actual sample that responded to the survey as described above were all the banks in the sample plan and top-marketing executives participated in the data collection. This was achieved through prior talking to them to set up the rapport for the study and explaining why the study is being carried out. The table below explains the type of resource interviewed. 
DOI: $10.21522 /$ TIJMG.2015.03.02.Art002

ISSN: $2520-310 \mathrm{X}$

Table 4.1. Details of respondents

\begin{tabular}{|l|l|l|l|}
\hline BANK & RESPONDENT & LEVEL & TYPE OF BANK \\
\hline 1 & Head of Marketing and Retail & Exco & Local \\
\hline 2 & Head of Marketing & Exco & Local \\
\hline 3 & Head of Marketing & below Exco & International \\
\hline 4 & Head of Retail Banking & Exco & International \\
\hline
\end{tabular}

As per the table above, the people that responded to the study survey were mostly top level of the marketing department except for one bank where a one level below executive committee was used. However, in this one bank, the person runs the marketing section but reporting directly to the Managing Director which in essence presents the highest level. All the four respondents are seasoned marketing gurus having worked in various multinational companies. Each of them has managed Fast Moving Consumer Goods (FMCGs). All the four respondents have the relevant marketing training, qualifications, and some with international experience. Simply put, they have the knowledge of the marketing concept and all the requirements of its implementation.

\section{History of bank establishment in Malawi and marketing resourcing}

From the sampled banks which comprised of local and integrational banks at the ratio of 50:50, it was observed that some of the banks are as old as fifty years. This means such bank has seen Malawi through the independence ladder. However, the names may have changed over the time and ownership as well. Some of the banks interviewed as local and less than 20 years of existence. All most all banks confirmed that marketing is a new phenomenon in the banking industry in Malawi. More concentration and efforts are placed on core banking activities. Could also be that in the early days of independence, there were few banks and competition was not an issue. As more and more banks opened up in the $20^{\text {th }}$ century, it became evident that some marketing skills were required. This saw the recruitment of various marketing people in the banks. Despite, realization of the need for marketing, it appears all banks have not really resourced their banks properly per with the demand of marketing work. All the four respondents unanimously agreed that their marketing resource was not enough for the demands of marketing. In one particular bank, there only one marketing person. Despite the knowledge these marketing professionals have, the space to implement the full marketing concept is compromised due to either lack resources or no support at all as all top managers feel marketing is not a core function of the bank. It must also be noted that in the bank with one marketing resource, they could be depending on their head office for other marketing initiatives with the local resource just implementing. However, prudent marketing requires that the marketing concept be fully implemented and that would need extra hands. The other three banks reported having only three members of staff in the marketing department with each vehemently saying the resourcing is not enough to execute critical roles of the bank in as far as marketing is concerned. In parallel, other marketing oriented companies like mobile industry, which are less than 15 years old on the market, possess vast marketing department staff. It is evident therefore that the banking industry in Malawi is not adequately resourced. These axillary companies have put more resources on marketing to drive a full agenda for the marketing concept implementation. Despite having regional establishment for support, there is need for local marketing team to lead the company in insight generation, consumer feedback and customer service as well as brand management in line with company philosophy.

While the marketing departments could be under resourced, they were well placed in the organization at least at the executive committee level. All most all banks confirmed executive committee members. This is critical as participation in key decisions of the banks is ensured from marketing point of view. It also means the marketing executives help $\mathrm{n}$ generating the strategies for the bank and partly implementation of the marketing concept 


\section{Technology usage in the banks}

Banks are naturally a high technology business sector and the world has seen tremendous improvements in banking facilities. In Malawi as noted from all the respondents, technology in highly used especially in areas of automatic tailor machines (ATM), swift transfers amongst banks, internet banking and mobile money, which has added to the list of recent developments. All banks confirmed having wide use of technology. Social media as well as short message broadcast are amongst the widely used vehicles by banks today. Through these vehicles, some banks have confirmed taking advantage of advanced technology to get customer feedback on some of their offering to the market. While these are plausible developments, they have brought with them open discussions forum where customers and marketers issues are laid open on the ground. If an issue is negative in nature, the bank suffers more damage and would need to fix the issue quickly. It was common from all banks to note that customers have making comments on social media about the services being offered either commendation or querying the services. Recently, all banks in Malawi were upgrading their systems, in some cases, the system upgrades came with varying balances and deductions from peoples accounts erroneously, these and many more brought the banks into lime light. It means resourcing these banks with all skills that marketing needs is more than vital today where all issues are discussed openly on social media. On a positive note, if a discussion is positive and appreciative in nature, it feels good to have free endorsements from customers. Such endorsements are shared widely on social media just like the negative comments. It is a pity though that negative comments go more viral that the positive comments. This is where the marketing tem need to be equipment with enough resources so that one is managing the digital world of the banking industry in relation to customer's needs. Through such interaction, the bank need to ensure it gives relevant information on issues being raised other than ignoring them. As for positive comments, the bank must take advantage to amplify them on social media and or other media.

The banks confirmed that technology has greatly improved the bank efficiencies in introduction of new products as well as message delivery to its customers whenever the banks need to send updates. Message broadcast on mobile platform has been key in updating customers with any issues that need their knowledge. Speed to marketing was also noted as one of the key benefit from technology, which all banks subscribe to. All respondents recognized the ease of business transaction that has come through with technology. Customers can easily open accounts using the bank's websites, which is the past, would only need physical presence at the bank. All respondents confirmed that customers are able to transact without necessarily coming to the bank. The integration with mobile companies for mobile banking has increased the financial inclusion number, which for a long time has been stagnant. With mobile banking which came into Malawi only from 2012, Malawi banking industry is widely using mobile platform for its banking services on offer. Mobile penetration being estimated at $38 \%$ of Malawi population using mobile phones. The banks are also increasing payments via point of sale machines placed in various vendors but this is yet to grow as few vendors make use of them. Electronic payment using the Automatic Transmission Machine (ATM) cards have increased but to a limited few due to the visa card which are being introduced now for the past year and half. Previously, most of the cards were not enabled for electronic payment but just cash withdrawals. This is fast changing, as all costs being issued now are visa enabled making a step towards cashless society, which is prevalent in the western world.

Use of technology to drive marketing agenda has been widely used as confirmed through the interviews with banking officials. Simple feedback is generated from consumers, which would mirror the consumer insight activators where consumers / customers provide feedback.

\section{Marketing concept practiced in the banking industry}

From the sample interviewed, it was prevalent from most banks that it is a tall order to accomplish the demands of marketing requirements. Almost all banks have challenges of resources to allocate to each requirement of the marketing concept. It was felt by most banks that both personnel and financial muscle 
DOI: $10.21522 /$ TIJMG.2015.03.02.Art002

ISSN: $2520-310 \mathrm{X}$

is limited in the marketing department such that the budget for marketing is not adequate to drive the marketing agenda as defined in the conceptual framework figure 1.5. In proxy companies like mobile companies or manufacturing companies where these marketing executives have worked before, the marketing departments are well resourced both financially and personnel wise. With proper financial resources, one is able to carry out all the needed research studies to know more about its customers, products in use and future habits and attitudes as they emerge. Marketing audit is key as it conducts an audit necessary for the execution of the marketing function especially in this ever-competitive world. From the marketing concept, companies are able to monitor customer or consumer. Consumer needs and wants are necessary to gauge what products to introduce on the market and how to satisfy customers better than competitors. The main thrust of the marketing strategy is the focus on the pull by consumers and customers through offering of best value products. The common practice in the banks as per the feedback indicates that with tight resource, not much of the marketing audits are being conducted. In some banks, audits are done but not as often as would be the case with other companies in the country dealing with FMCGs. It was apparent from all the interviewed banks that the focus is mostly on the core banking activities rather than marketing. All banks voiced out the need to enhance their marketing departments in order to fulfil all the requirements of the marketing. Doing marketing audits periodically require funds which again as confirmed by most of the banks is limited. The budgets are more skewed to core banking activities and marketing is left at the back end when budgeting is being allocated. With the current technological advancement, more audits and customer feedback could be planned but still more, there is deliberate need to resource the department properly for its effective. Interestingly, both local banks and international banks shared the same view in as far as marketing resourcing is concerned. It can be concluded therefore that the marketing department is not that prioritize in the banking industry. This could be due bank industry evolution in the country and delayed competition over time, as they were few banks in Malawi for a long time.

Delivery of marketing concept desires that all departments work together to ensure customer value is maximized. Bhasin (2016) illustrates holistic marketing with a togetherness symbol where a team is working together representing different departments of the company. These departments could be marketing, Sales, Finance, Accounting, Operation, Human Resources etc. etc. In market orientation, this is critical as the entire organization need to drive the same efforts towards satisfying consumer needs. In a highly competitive world, consumer and customer are kings hence working together is the right thing to do. In the survey responses, all varied answers were given in the manner the departments work together. This suggests that more needs to be done to enforce the togetherness and oneness in order to drive the marketing agenda that will ensure success of the brands and organization.

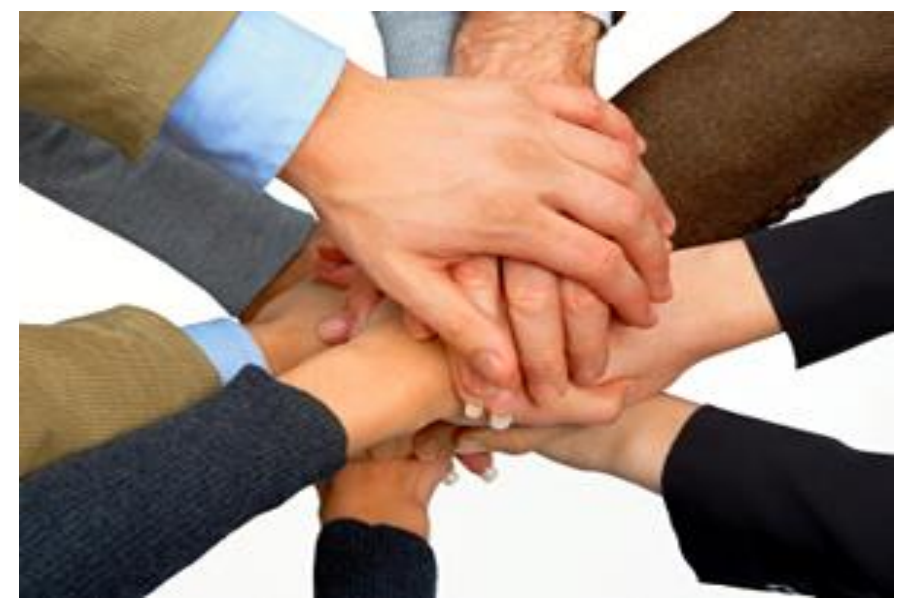

Figure 4.4. Togetherness at work as departments

Bhasin Hitesh 2016: Holistic Marketing Concept. 
An organization with different department where Research and Development (R\&D) together with product development rely on all other departments especially Sales and Marketing to launch products that meet consumer and customer needs.

\section{Marketing orientation in the banking industry}

From the survey data, it was prevalent that with limited resourcing of the marketing department both financial and human capital, the level of marketing orientation is somewhat compromised. Despite some behaviours relating to some processes of the marketing orientation, generally participants were of the view that more need to be done on this front. Most of the participants in this interview strongly agreed that the current setup of the banking industry is skewed to core banking activities with marketing playing second fiddle. Contrary to what the marketing orientation desires of the behavior of an organization that must focus all attention to marketing activities by all departments.

Tomaskova (2009) brings out the new methods of measuring market orientation that among others includes supply side. This methods looks at external analysis, customers and distributors, competitors, suppliers and inter-functional coordination. In the survey undertaken, almost all participants concurred that not all these analysis are being done to the book. On the other side, it is also advised that some of the processes of the marketing orientations especially those that relate to product development and innovation are led at group level in those banks that have international ownership. However, simple research works are being g practiced in Malawi but nor as often as would be desires in a fully-fledged market oriented firm. It was a general view from participants that that the banks are not market oriented in the conduct of business now. Some traces of the needed behavior is being noticed in the banking industry but with the marketing not coordinating this effort, it leaves a lot to be desired.

\section{Conclusion}

From the study, it is clear that most of the banks do have the Marketing executive officer at the top lever of the Bank's executive committee. However, resourcing is an issue for the marketing department as observed in all banks. This means implementation of the marketing concept is compromised. Although there is that notion that international banks have back up resource at their head offices, it must be noted though that market conditions for each operation are different requiring complete resourcing of the department. There is visible usage of technology as observed in all the banks but more can be done to enhance customer engagement and satisfaction. It therefore follows that each of the banks felt they are not fully marketing oriented as most of the weight in the banking services is placed on operations. There is therefore need to conduct a full-scale research in this area to determine statistically the marketing orientation of the banking industry which is critical to the economic growth of the country. This study was important to check the current marketing orientation as practiced in the service industry of the banking sector.

\section{Acknowledgement}

This work could not have been completed without the assistance and participation of the marketing personnel in the four banks that participated in the discussions guide. I am greatly indebted to their time for this research in responding to the in-depth questionnaire and telephone calls to get more information.

\section{References}

[1]. Ajay K. Kohli, Bernard J. Jaworski, Ajith Kumar Source: Journal of Marketing Research, Vol. 30, No. 4 (Nov., 1993), pp. 467-477 Published by: American Marketing Association Stable URL: http://www.jstor.org/stable/3172691 [2]. Avlonitis, George J., and Spiros P. Gounaris. "Marketing Orientation And Company Performance: Industrial vs. Consumer Goods Companies." Industrial Marketing Management 26.5 (1997): 385-402. Web.

[3]. Bingu wa Muthalika (2006), Malawi Growth and Development Strategy 2006-2011, Government of Malawi 
DOI: $10.21522 /$ TIJMG.2015.03.02.Art002

ISSN: $2520-310 \mathrm{X}$

[4]. Boyce, C; Neale P, 2006. Conducting in-depth interviews: A guide for conducting in-depth interviews for evaluating input. Pathfinder International.

[5]. Brand Royalty: How The World's Top 100 Brands Thrive And Survive". Journal of Brand Management 13.2 (2005): 167-169. Web.

[6]. Deloitte Access Economics 2014. Competition in Retail Banking. Australian Bankers Association Inc. George Street, Sydney. www.delaitteaccesseconomic.com.au.

[7]. Dupas, P, Karlan D, Robinson, J Ubfal, D (2017), Banking the Unbanked? Evidence from three countries, Uganda, Malawi and Chile. IRBs of UCLA, UC Santa Cruz, and Stanford University.

[8]. Ernest and Young (2014) Global Consumer Banking Survey. Accessed April 24, 2017: Winning through customer experience. www.ey.com/globalconsumerbankingsurvey

[9]. http://www.ey.com/Publication/vwLUAssets/EY_-

[10]. http://www.ey.com/Publication/vwLUAssets/EY_-

[11]. http://www.intracen.org/uploadedFiles/intracenorg/Content/Redesign/Sector/Global_Services_Network_blog/

Malawi.pdf

[12]. http://www.iobmalawi.com/banking.htm

[13]. http://www.marketing91.com/marketing-concepts/

[14]. http://www.nber.org/books/stig56-1

[15]. http://www.photius.com/world_fact_book_2015/malawi/malawi_economy.html

[16]. https://docs.google.com/forms/d/1Tcib_AiT6PnPR_Ft11h4tqq7n7jaOvnd9OsVL1OEs6o/edit?c=0\&w=1\# responses

[17]. https://docs.google.com/forms/d/1Tcib_AiT6PnPR_Ft11h4tqq7n7jaOvnd9OsVLlOEs6o/edit?c=0\&w=1\# responses

[18].https://en.wikipedia.org/wiki/National_Bank_of_Malawi

[19]. https://www.cia.gov/library/publications/the-world-factbook/fields/2012.html

[20]. https://www.export.gov/article?id=Malawi-telecommunications

[21]. https://www.usitc.gov/publications/332/pub4440c.pdf

[22]. Inge Eva Tamaskova. The current methods of measuring market orientation. Journal of European Research Studies. Vol XII (3). 2009.

[23]. International Trade Centre, 2012, Service snapshot for Malawi, Service for Good. www.intracen.org

[24]. Kohli, Ajay K. and Bernard J. Jaworski (1990), "Market Orientation: The Construct, Research Propositions, and Managerial Implications," Journal of Marketing, 54 (April), 1- 18. Kotler, Philip

[25]. Kohli, Ajay K., and Bernard J. Jaworski. "Market Orientation: The Construct, Research Propositions, and Managerial Implications". Journal of Marketing 54.2 (1990): 1. Web.

[26]. Malawi Communications and Regulatory Authority (Macra) 2015. Strategic Plan 2015 - 2020. Macra, Blantyre, Malawi

[27]. Metre, Kanika. "Using Mobile Banking Services to Improve Financial Access for the Poor: Lessons from Kenya, the Philippines, the United States, Haiti, and India". Policy Perspectives 18.1 (2011): 6. Web.

[28]. Muyeri, M K (2015). Improving access to the poor to financial services. A report prepared for the General Economics Division of the Planning Commission to serve as a background study for preparing the 7rg Five Year Plan (2016-202) of Bangladesh.

[29]. Stigler, George. "Classification and Characteristics of Service Industry". Trends in employment in Service Industry 0-87014-058-2.0-87014-058-2 (1956): n. pag. Print.

[30]. United Nations. Economic development in Africa report. 2015. Unlocking the potential of Africa's service and development. United Nations Conference on Trade and Development. UNICTAD. 